\title{
JAUNIEŠU G̦EOGRĀFISKĀ MOBILITĀTE UN AKTIVITĀŠU SASNIEDZAMĪBA JELGAVAS NOVADĀ
}

\author{
Ģirts Burgmanis, Iveta Sproǵe \\ Latvijas Universitāte, G̣eogrāfijas un Zemes zinātṇu fakultāte, \\ e-pasts: gjirts_rhv@inbox.lv, sprogeiveta@inbox.lv
}

\begin{abstract}
Anotācija. Pēdējo pāris desmitgažu laikā Latvijā negatīva dabiskā pieauguma un migrācijas saldo rezultātā strauji samazinājies iedz̄ivotāju skaits, kam seko pieejamo pakalpojumu apjoma sarukums. Izteiktas pārmaiņas vērojamas lauku reǵionos, kur depopulācijas tendences redzamas visuzskatāmāk, un rosina nepieciešamību pēc plašākas diskusijas par pakalpojumu sasniedzamību un aktivitāšu iespējām iedzīvotājiem Latvijas novados.

Pētījumā, izmantojot tiešsaistes pilotaptaujas laikā iegūtos datus $(\mathrm{n}=117)$, analizēta jauniešu vecumā no 12 līdz 20 gadiem pārvietošanās izturēšanās uz nozīmīgākajām ikdienas aktivitāšu vietām (skolu un ārpusskolas nodarbībām - pulciṇiem) Jelgavas novadā. Rezultāti rāda, ka pašlaik Jelgavas novadā izglītības iestādes un pulciņu sasniedzamība ir augsta, jo lielākā daḷa (65-70\%) jauniešu spēj 15 minūšu laikā nokḷūt līdz izglītības iestādei un ārpusskolas nodarbības vietai. Augstā sasniedzamība skaidrojama ar esošo izglītības iestāžu izvietojumu novada lielākajos ciemos. Nākotnē turpinoties skolu tīkla optimizācijai un restrukturējot izglītības iestādes Jelgavas novada lielciemos, skolu un pulciņu sasniedzamības rādītāji pazemināsies, t.i., nokḷūšanai nepieciešamais laiks augs, rosinot vērtēt ne tikai jauniešu pārvietošanās izturēšanos, bet arī sociālekonomiskos aspektus.
\end{abstract}

Atslēgas vārdi: jaunieši, ǵeogrāfiskā mobilitāte, izglītības sasniedzamība, pārvietošanās izturēšanās, Jelgavas novads.

\section{Ievads}

Pēdējos gados, samazinoties iedzīvotāju un īpaši jauniešu skaitam Latvijā, aktualizējies jautājums par izglītības iestāžu tīkla ekonomisko efektivitāti un restrukturizācijas nepieciešamību. Lai arī skolu tīkla optimizācijas norise vērojama visos valsts reǵionos (izṇemot Pierīgu), tomēr īpaši aktuāla tā ir lauku teritorijās, kur 
negatīvās iedzīvotāju skaita pārmaiṇas ir vērojamas visizteiktāk. Vienlaicīgi ar ekonomiskajiem ieguvumiem, izglītības iestāžu skaita sarukumam, iespējams prognozēt arī negatīvas sekas. Starp nozīmīgākajām īpaši akcentējama iespējamā izglītības iestāžu sasniedzamības mazināšanās. Turklāt, n,emot vērā, ka laukos, kur skolas funkcionē ne tikai kā mācību iestādes, bet arī kā nozīmīgi brīvā laika formālo aktivitāšu centri, problēma kḷūst vēl izteiktāka un rosina izvērtēt jauniešu iespējas piekḷūt jebkāda veida izglītībai. Vairāki iepriekšējie pētījumi liecina, ka ierobežota izglītības sasniedzamība laika, attāluma un sociālekonomisko apstākḷu kontekstā, nākotnē var ietekmēt jauniešu iespējas veiksmīgi un vienlīdzīgi iesaistīties darba tirgū (Farrington, Farrington 2005; Farrington 2007). Lai līdzsvarotu savas iespējas nākotnē, ğimenes ar bērniem un jaunieši ir spiesti sasniedzamības problēmu risināt, lemjot par palikšanu dz̄ivesvietā vai tās pamešanu un došanos uz apdzīvotajām vietām, kur izglītības iespējas ir daudz lielākas. Līdz ar to izglītības iespēju sasniedzamības problēmas saasināšanās Latvijas gadījumā var izraisīt vēl izteiktākus lauku reǵionu depopulācijas riskus.

Tāpēc, lai apzinātu problēmas nopietnību, nepieciešams padziḷināti aplūkot to faktoru kopu, kas raksturo sasniedzamību - mobilitātes, ǵimenes materiālās iespējas, un sociādemogrāfiskos faktorus. Rakstā, aplūkojot Jelgavas novada piemēru, mēs analizēsim jauniešu pārvietošanās iespējas uz nozīmīgākajām ikdienas aktivitāšu vietām (skolas un ārpusskolas nodarbībām - pulciniem) lauku teritorijās.

\section{Jaunieši un géogrāfiskā mobilitāte}

Literatūras avotos jēdziens 'jaunietis' tiek definēts, izmantojot atšķirīgas hronoloǵiskās robežas. Jauniešu sociālās grupas pētījumos par jauniešiem tiek uzskatītas personas no 13 līdz 25 gadiem (Trapenciere 2006) vai, piemēram, no 16 līdz 25 gadiem (Valentine 2003). Savukārt politikas dokumentos un statistiskajos pārskatos jauniešu sociālā grupa tiek identificēta ar vecuma posmu no 15 līdz 25 gadiem (European Commision 2001) vai no 15 līdz 24 gadiem (United Nations Department of Economic and Social Affair 2013). Visas minētās pieejas izriet, savietojot biologiisko un sociālo vecuma posma kontekstu, kur dominējoša loma modernajā sabiedrībā ir tieši sociālajai un kultūras praksei.

Salīdzinot ar bērnu ikdienas dz̄ivi, jauniešiem raksturīga paugstināta mobilitāte, kas izriet no mazāka vecāku veidotu telpisko ierobežojumu skaita un nepieciešamības nokḷūt līdz plašākam aktivitāšu vietu (izglītības iestādei, nodarbībām, draugiem, u.c.) klāstam. Līdz ar to jauniešiem patstāvīgi, ievērojot savas iespējas, jāpieṇem lēmumi par atbilstoša pārvietošanās veida izvēli atkarībā no veicamā attāluma, pieejamā laika un apvienojamo aktivitāšu skaita. Iepriekšējie pētījumi parāda, ka pārvietošanās veida izvēli galvenokārt ietekmē attālums no dzīvesvietas līdz aktivitātes vietai un vecāku privātā auto lietojuma paradumi un regularitāte (McDonald 2008; Hjorthol, Fyhri 2009; Burgmanis 2012). Jaunieši, kuri dzīvo tālāk no aktivitāšu vietām un kuru vecāki regulārāk izmanto auto, biežāk izvēlas doties uz skolu vai ārpusskolas aktivitātēm ar auto kopā ar vecākiem nekā izmantot citus pārvietošanās veidus. Piemēram, Mcdonald (2008) norāda, ka 1,6 kilometri vai aptuveni 15-18 minūtes līdz izglîtîbas iestādei ir 
robeža, kura var ietekmēt jaunieša lēmumu, izvēloties pārvietošanās veidu par labu auto vai sabiedriskā transporta izmantošanai. Savukārt citos pētījumos uzsvērta vecuma, dzimuma (O'Brien et al. 2000; Burgmanis 2014), ǵimenei pieejamo privāto auto skaita (Pont et al., 2009), fiziskās un sociālās vides drošības (Schlossberg et al. 2006), satiksmes drošības un vecāku satraukuma pakāpes (Fyhri, Hjorthol 2009; McDonald et al. 2010) loma pārvietošanās veida izvēelē.

\section{Sasniedzamība lauku reǵionos}

Literatūrā sasniedzamība tiek aplūkota kā cilvēku iespēju nokḷūt līdz pakalpojumiem un piedalīties aktivitātēs, kas raksturīgas jebkurai modernai sabiedrībai (Church et al. 2000). Nozīmīgākie pakalpojumi, kuriem būtu jābūt viegli pieejamiem, ir fiziskā drošība, veselība un izglītība. Lauku teritoriju konstekstā sasniedzamība tiek uzlūkota kā 'lauku izaicinājums' (Moseley 1979), t.i., pakāpeniski samazinoties apdzīvojuma blīvumam, sabiedriskā autobusa un pakalpojumu piedāvājumam, attālumam un nepieciešamajam laikam augot, palielinās telpiskā nošķirtība, kas atspoguḷjojas kā iespēju sarukums. Neliels attālums ḷauj iedzīvotājiem vienkāršāk, ērtāk, biežāk un lētāk sasniegt nepieciešamos pakalpojumus, savukārt, augot attālumam, cilvēki ir daudz vairāk spiesti novērtēt tēriņus un patērējamo laiku (Naes 2006). Līdz ar to aizvien lielāka nozīme lauku teritorijās, lai nokḷūtu līiz pakalpojumiem un ikdienas aktivitātēm, ir privātajam autotransportam un tā skaitam mājsaimniecībasā.

Lai arī lauku teritorijās sasniedzamības atškirības iedzīvotāju vidū skaidrojamas ar mobilitātes iespējām, atālumu un patērēto laiku līdz pakalpojumam, tomēr transports un pārvietošanās izturēšanās ir tikai viena problēmas puse (Farrington, Farrington 2005). Otru pusi veido iedzīvotāju sociāldemogrāfiskās (piem., dzimums, vecums, etniskā piederība), sociālekonomiskās (piem., ienākumi, nodarbinātība) iezīmes un dzīvesvietas novietojums attiecībā pret pakalpojuma atrašanās vietu (Farrington, Farrington 2005). Tāpēc sasniedzamības jēdziena kompleksais saturs ḷauj to uzlūkot arī kā sociālo atstumtību raksturojošu indikatoru (Farrington 2007).

\section{Iedzīvotāju skaita pārmaiṇas un un izglītības iestāžu tīkla optimizācija Jelgavas novadā}

Jelgavas novadā, līdzīgi kā visā Latvijāa pēc valsts neatkarības atjaunošanas nepārtraukti ir sarucis iedzīvotāju skaits. Atbilstoši LR Centrālās statistikas pārvaldes datiem no 1991. gada, kad Jelgavas novada teritorijā dzīvoja aptuveni 30000 iedzīvotāji, līdz 2014. gadam (23778 iedzīvotāji) iedzīvotāju skaits samazinājies par $21 \%$. Straujais iedzīvotāju skaita samazinājums saistīts ar negatīvu dabisko pieaugumu un migrācijas saldo (1. attēls - precīzi dati pieejami tikai par laika periodu no 1996. līdz 2014. gadam). 


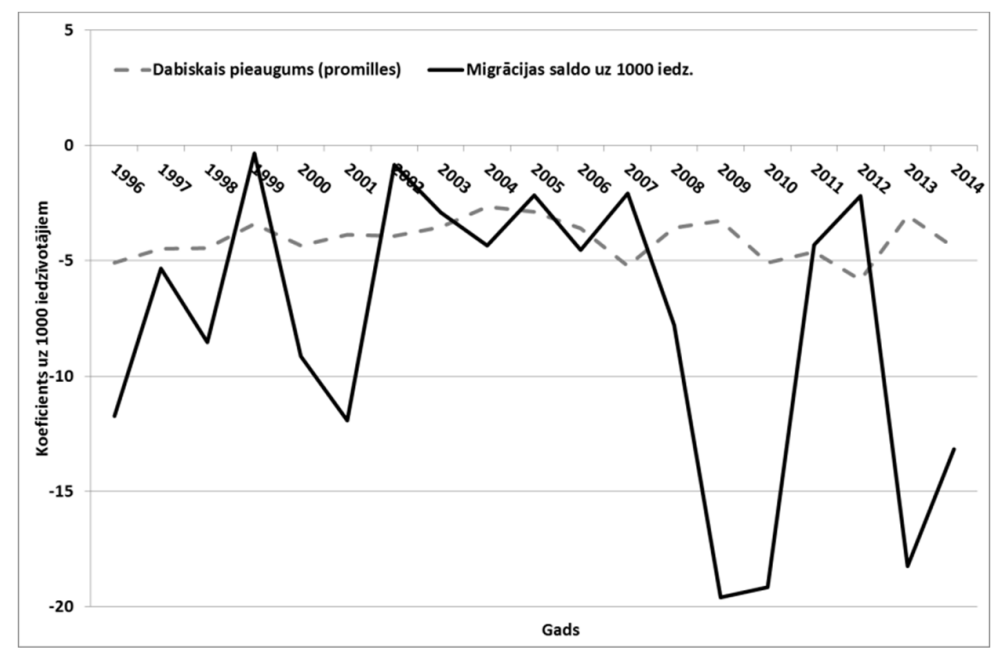

1. attēls. Dabiskā pieauguma un migrācijas saldo izmainās Jelgavas novadā laika posmā no 1996. gada līdz 2014. gadam. Datu avots: LR CSP tiešsaistes datu bāze (tiešsaistes tabulas piekluves kods: ISVG031)

Acīmredzamās pārmaiņas atspoguḷojas ar̄̄ jaunāku vecuma grupu novada iedzīvotāju skaita sarukumā. Kopš 2006. (pieejami dati par konkrēto periodu) līdz 2014. gadam skolas vecuma jauniešu skaits samazinājies par 37\%, t.i., vēl straujāk nekā kopējais iedzīvotāju skaits novadā. 2006. gadā Jelgavas novadā pašlaik ietilpstošo novadu vispārizglītojošajās skolās mācījās 3387 izglītojamie, savukārt deviņus gadus vēlāk vairs tikai 2150 .

Pārmaiņas iedzīvotāju skaitā un izvietojumā, kā arī ekonomiskā krīze 2008. gadā rosināja Izglītî̉bas un Zinātnes ministriju darboties pēc uzṇēmējdarbības principiem, lai sakārtotu izglītības iestāžu tīklu visā Latvijā un tajā skaitā arī Jelgavas novadā. Uz 2014. gada 1. septembri Jelgavas novadā darbojās 13 vispārizglītojošās skolas un 4 to filiāles. Salīdzinot ar 1996. gadu, kad tagadējā Jelgavas novada teritorijā darbojās visvairāk vispārizglītojošo izglītības iestāžu - 29, skolu skaita sarukums ir ievērojams (41\%). Turklāt 2015. gada 1. septembrī tika aizvērta Elejas vidusskolas Lielplatones filiāle, kā arī ar 2016. gada septembri plānots aizvērt Svētes pamatskolas Glūdas filiāli.

Statistikas datu analīze liecina, ka, turpinot samazināties jauniešu un izglītības iestāžu skaitam Jelgavas novadā, satraukumam par izglītības sasniedzamību Jelgavas novadā, tāpat kā visā valstī, ir pamats. Sarūkot izglītības iestāžu skaitam un jaunietim mainot skolu, aug attālums un patērtētais laiks, t.i., grūtības, lai sasniegtu mācību iestādi. Līdz ar to palielinās telpiskā nošķirtība. Sasniedzamības problēmas aktualitāti apliecina SIA "Karšu izdevniecības Jāṇa sēta" un SIA “Grupa 93” (2015) kopīgi veiktais pētījums, kurā tiek vērtēta un analizēta izglītības iestāžu sasniedzamība un veidoti ieteikumi Izglītības un Zinātnes ministrijai racionālai turpmākai izglītības iestāžu tīkla restukturizācijai valsts plānošanas reǵionu mērogā. 


\section{Dati un metodes}

Pētījuma dati tika iegūti pilotaptaujas laikā 4 Jelgavas novada izglītības iestādēs (Elejas vidusskolā, Stalıǵenes vidusskolā, Vircavas vidusskolā, Svētes pamatskolā) aptaujājot kopā 117 skolēnus vecumā no 12 līdz 20 gadiem. Pilotaptaujas mērkis bija ne tikai atklāt Jelgavas novada jauniešu ikdienas mobilitātes un aktivitāšu sasniedzamības iezīmes, bet arī aprobēt izstrādātās aptaujas anketas efektivitāti. Pilotaptaujas fāzē anketa tika izvietota tiešsaistē un nosūtīta visiem minēto 4 skolu skolēniem portālā www.e-klase. Tiešsaistes aptaujas metode aizvien biežāk tiek izmantota pētniecībā, jo l̦auj iegūt primāros datus bez ǵeogrāfiskiem šķēešş̧iem (McCollum, Apsite-Berina 2015). Aptaujas anketa sastāvēja no vairākām dalāām, kurās tika noskaidrotas respondentu sociāldemogrāfiskās iezīmes, pārvietošanās paradumi, patērētais laiks līdz ikdienas aktivitātēm, vecāku pārvietošanās paradumi, dažādu pakalpojumu sasniedzamība un tās vērtējums.

Turpmākajā datu analīzē tika atlasītas un iekḷautas atbildes no 96 (82\%) korekti aizpildītām anketām. Datu analīzē netika iekḷautas respondentu atbildes, kuru dzīvesvieta atrodas ārpus Jelgavas novada. Pētījumā aplūkota divu aktivitāšu - izglītības iestādes un ārpusskolas nodarbību sasniedzamība Atškirīīā no vairākiem iepriekšējiem pētījumiem (sk., piemēram, McDonald 2008) attāluma no dzīvesvietas līdz aktivitātēm kā atkarīgais (dependent) mainīgais izmantots laiks.

\section{Rezultāti}

Rezultāti liecina, ka lielākā daḷa jauniešu - 42\% uz skolu dodas kājām vai ar velosipēdu, 27\% ar skolas autobusu, 18\% skolā nokḷūst ar automašīnu, savukārt 13\% ar sabiedrisko transportu. Salīdzinot patērēto laiku, lai nokḷūtu skolā un izmantojot 15 minūšu intervālu kā atskaites kritēriju, redzams (2. attēls), ka visvairāk - 87\% (no kopējā gājēju un velobraucēju skaita) intervālā iekḷaujas skolēni, kuri skolā nokḷūst, ejot kājām vai braucot ar velosipēdu. Nedaudz mazāk (82\%) ir jauniešu, kuri, izmantojot auto, spēj nokḷūt skolā 15 minūšu laikā. Savukārt tikai 52\% un 33\% no jauniešiem, izmantojot skolas autobusu un sabiedrisko transportu, spēj nokḷūt skolā 15 minūšu laikā. To apliecina arī vidējā patērētā laika salīdzinājums starp četriem transporta veidiem. Visātrāk jaunieši nokḷūst skolā, izmantojot auto - 11,3 minūtes un ejot - 13,6 minūtes. Savukārt visilgākais laiks nepieciešams, braucot ar skolas autobusu vai sabiedrisko transportu, attiecīgi 20 un 21,7 minūtes.

Aplūkojot patērēto laika apjomu, lai sasniegtu izglītības iestādi Jelgavas novadā, neatkarīgi no pārvietošanās veida, redzams, ka $70 \%$ jauniešu, spēj nokḷūt skolā 15 minūtēs. Tāpat vidējais patērētais laiks ir 16 minūtes. 


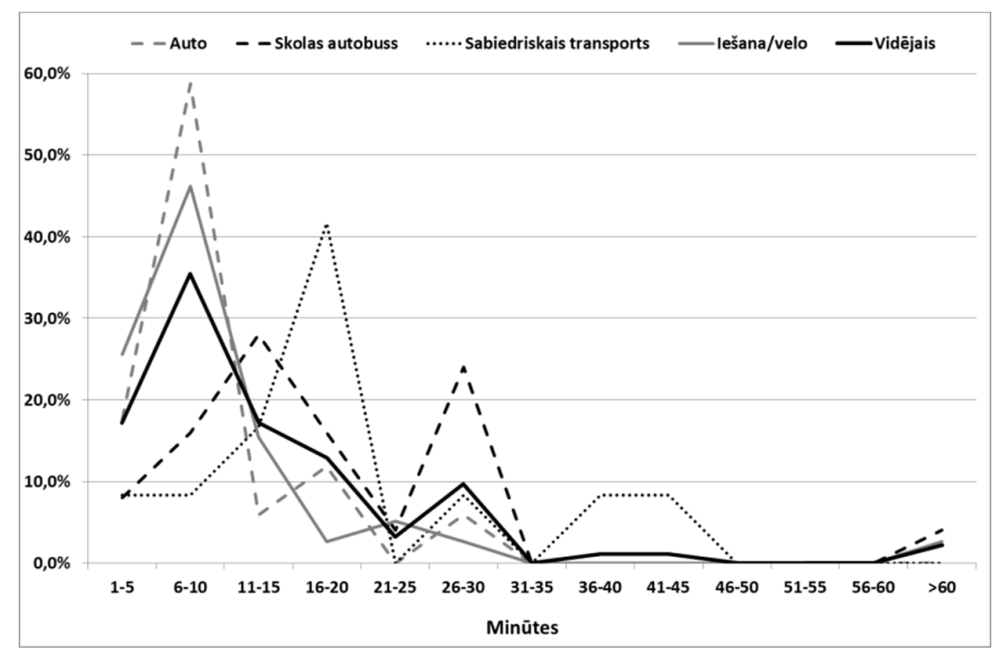

2. attēls. Braucienu ilguma uz izglītības iestādi salīdzinājums pēc pārvietošanās veida (sagatavoja autori)

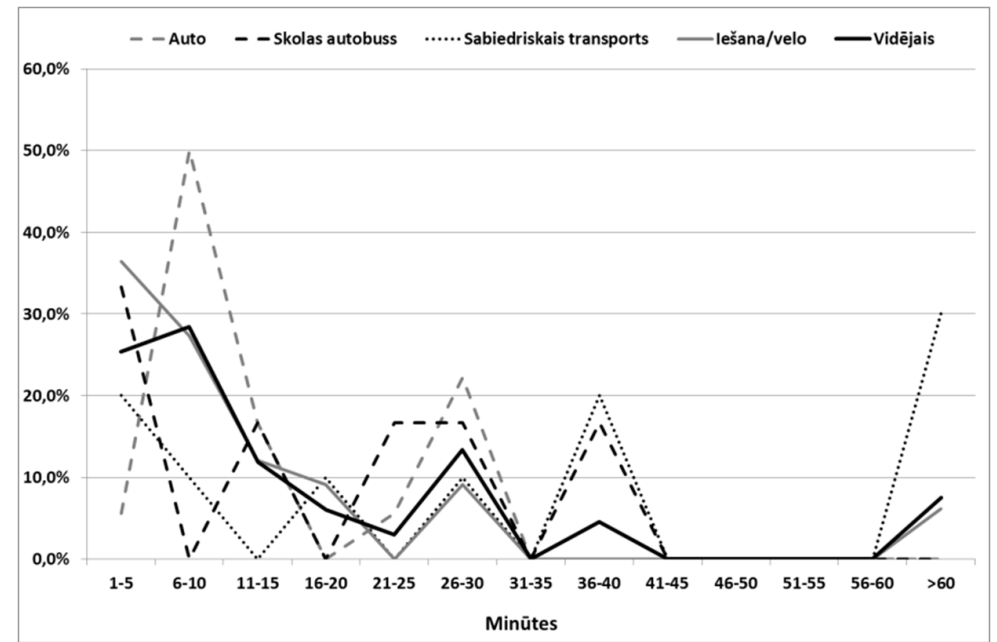

3. attēls. Braucienu ilguma uz ārpusskolas nodarbībām salīdzinājums pēc pārvietošanās veida (sagatavoja autori)

Nedaudz atšķirīga situācija vērojama, aplūkojot pārvietošanās izturēšanos, dodoties uz ārpusskolas nodarbībām. Palielinājies jauniešu skaits, kuri uz nodarbībām dodas kājām - 46\%, ar auto - 30\%, sabiedrisko transportu - 17\%, savukārt tikai 7\% uz ārpusskolas nodarbībām dodas ar skolas autobusu. Iegūtie rezultāti nav pārsteidzoši, jo ārpusskolas nodarbību vieta ne vienmēr var sakrist ar skolas atrašanās vietu, tādējādi rosinot jauniešus izvēelēties citu pārvietošanās veidu, lai nokḷūtu līdz tām. To, ka ārpusskolas nodarbību norises vieta atšķiras no skolas novietojuma, pierāda arī vidējā patērētā laika apjoma salīdzinājums. Lai nokḷūtu ārpusskolas nodarbībās, jauniešiem ir nepieciešams vidēji ilgāks laiks (19,2 minūtes) nekā, lai nokḷūtu līdz skolai. Aplūkojot vidējo patērēto laiku pēc pārvietošanās veida redzams, ka nedaudz palielinājies nokḷūšanas laiks tiem jauniešiem, kuri uz ārpusskolas nodarbībām dodas kājām (15,4 minūtes) un ar auto (15,2 minūtes), nemain̄̄gs palicis laiks tiem, kuri uz 
nodarbībām dodas ar skolas autobusu - 20 minūtes. Savukārt ievērojami audzis patērētais laiks tiem jauniešiem, kuri uz nodarb̄̄bām dodas ar sabiedrisko transportu 38,6 minūtes. Tāpat nedaudz palielinājies arī vidējais patērētais laiks (19,2 minūtes), lai nokḷūtu uz pulciņiem.

3. attēls atklāj, ka 66\% jauniešu spēj nokḷūt līdz ārpusskolas nodarbību vietai 15 minūšu laikā. Salīdzinot pārvietošanās veidus pēc 15 minūšu kritērija, redzams, ka 76\% no visiem jauniešiem, kuri uz ārpusskolas nodarbību vietu dodas kājām vai ar velo un $72 \%$ ar auto, spēj to sasniegt noteiktā kritērija robežās. Tāpat kā braucienos uz skolu vismazākais jauniešu īpatsvars, kuri spēj nokḷūt ārpusskolas nodarbības vietā 15 minūšu laikā, ir starp tiem, kuri brauc ar skolas autobusu - 50\% un sabiedrisko transportu $30 \%$.

\section{Secinājumi}

Pêtījumā aplūkoti tiešsaistes pilotaptaujas laikā iegūtie dati par bērnu un jauniešu vecumā no 12 līdz 20 gadiem pārvietošanās izturēšanos, dodoties uz skolu un ārpusskolas nodarbību vietām. Padzilināti analizēts pārvietošanās laikis un tā pārmaiṇas atkarībā no pārvietošanās veida.

Rezultāti liecina, ka lielākā daḷa jauniešu (65-70\%), neatkarīgi no izmantotā pārvietošanās veida, spēj nokḷūt līdz skolai vai ārpusskolas nodarbību vietai 15 minūšu laikā. Augstie sasniedzamības rādītāji saistīti ar pašreizējo pamatskolu un vidusskolu izvietojumu Jelgavas novada lielciemos (piemēram, Kalnciema, Staļǵenes, Elejas uc. vidusskolas), kur iedzīvotāju skaits svārstās no aptuveni 350 (Vircava) līdz pat 800 (Eleja). To apliecina augstais jauniešu īpatsvars, kuri dodas uz skolu (42\%) vai ārpusskolas nodarbībām (46\%) kājām vai ar velosipēdu un spēj galamērḳ̄ nokḷūt 15 minūšu laikā (attiecīgi $87 \%$ un $76 \%$ ). Iespējamā skolu slēgšana un restrukturizācija kādā no šiem lielciemiem, nākotnē, palielinoties attālumam un patēēêtajam laikam, lai nokḷūtu līdz skolai, var rosināt ievērojamas skolēnu pārvietošanās izturēšanās pārmaiņas.

Lai arī divu nozīmīgāko ikdienas aktivitāšu vietu sasniedzamība vērtējama kā ļoti laba, tomēr padzilịnāta nepieciešamā laika un pārvietošanās veida sakarību analīze liecina par tendenci, kas raisa piesardzību. Līdzīgi kā gājēju un velo braucēju gadījumā, daudz jauniešu, kuri dodas uz skolu vai ārpsusskolas aktivitāšu vietu ar auto (attiecīgi 70 un 72\%), arī spēj sasniegt tās 15 minūšu laikā. Savukārt visilgākais laiks nepieciešams tiem jauniešiem, kuri dodas uz abām aktivitāšu vietām ar skolas autobusu vai sabiedrisko transportu. Tādējādi var secināt, ka izglītības un aktivitāšu sasniedzamības rādītāji ir atkarīgi ne tikai no dzīvesvietas novietojuma, bet arī no automašīnas pieejamības un turpmākajos pētījumos rosina analizēt gan pārvietošanās izturēšanos raksturojošos rādītājus, gan sociālekonomiskos un sociāldemogrāfiskos aspektus. Sarūkot skolu skaitam un palielinoties telpiskajai nošķirtībai novadā, lai sasniegtu ikdienas aktivitāšu vietas, jauniešu dzīvē palielināsies auto pieejamības nozīme. Tāpēc jauniešiem no turīgākām gimenēm izglîtības un citu aktivitāšu sasniedzamība būs augstāka nekā jauniešiem no mazāk turīgākām ǵimenēm. Izglītības un aktivitāšu sasniedzamības atšķirības ilgtermiņā var veicināt vienas grupas priekšrocības pār otru darba tirgū. 


\section{Pateicība}

Raksts izstrādāts ar Valsts pētījumu programmas pētnieciskā projekta Nr. 5.2.4. „Sabiedrības atjaunošana, samazinot depopulācijas riskus, veicinot tautas ataudzi un saiknes ar diasporu" atbalstu.

\section{Atsauces}

Burgmanis, G. (2012). Travel Patterns of Children Living in Rural Areas of Riga Agglomeration: an Exploration of School Trips to Riga. Economic Science for Rural Development Conference Proceedings, 27, 42-48.

Burgmanis, G. (2014). Commuting patterns in Riga agglomeration: evidence from a survey analysis of youth. Regional Formation and Development Studies, 14 (3), 16-29.

Church, A., Frost, M., Sullivan, K. (2000). Transport and social exclusion in London. Transport Policy, 7, 195-205.

European Commision (2001). European Commision white paper: A new impetus for european youth. Brussels: Commission of the European communities.

Farrington, J. (2007). The new narrative of accessibility: its potential contribution to discourses in (transport) geography. Journal of Transport Geography, 15, 319-330.

Farrington, J., Farrington, C. (2005). Rural accessibility, social inclusion and social justice: towards conceptualisation. Journal of Transport Geography, 13, 1-12.

Fyhri, A., Hjorthol, R. (2009). Children's independent mobility to school, friends and leisure activities. Journal of Transport Geography, 17, 377-384.

Hjorthol, R., Fyhri, A. (2009). Do organized leisure activities for children encourage caruse?. Transportation research part A: policy and practice, 43(2), 209-218.

McDonald, N.C. (2008). Children's mode choice for the school trip: The role of distance and school location in walking to school. Transportation, 35 (1), 23-35.

McDonald, N.C., Deakin E., Aalborg A.E. (2010). Influence of the social environment on children's school travel. Preventive Medicine, 50, S65-S68.

McCollum, D., Apsite-Berina, E. (2015). Recruitment through migrant social networks from Latvia to the United Kingdom: Motivations, processes and developments. Migration Letters, 12(1), 50-66.

Moseley, M.J. (1979). Accessibility: The Rural Challenge. Methuen: London.

Naes, P. (2006). Accessibility, Activity Participation and Location of Activities: Exploring the Links between Residential Location and Travel Behaviour. Urban Studies, 43 (3), 627-652.

O’Brien, M., Jones, D., Sloan, D., Rustin, M. (2000). Children's Independent Spatial Mobility in the Urban Public Realm. Childhood, 7 (3), 257-277.

Pont, K., Ziviani J., Wadley, D., Bennett, S., Abbott, R. (2009). Environmental correlates of children's active transportation: A systematic literature review. Health \& Place, 15, 849-862.

Schlossberg, M., Greene, J., Paulsen, P., Johnson, B., Parker, B. (2006). School Trips: Effects of Urban Form And Distance on Travel Mode. Journal of American Planning Association, 72 (3), 337-346.

Trapenciere, I. (2006). Es rullēju, tu rullē. Vai viņš/viņa rullē? Cool...: Par jauniešu dzīves kvalitāti. B.Bela un T. Tisenkopfs (eds.) Dzìves kvalitāte Latvijā. Rīga: Zinātne, 110-152. 
United Nations Department of Economic and Social Affair (2013). UN Definition of Youth. United Nations: http://www.un.org/esa/socdev/documents/youth/fact-sheets/youthdefinition.pdf (20.02.2016.)

Valentine, G. (2003). Boundary Crossings: Transitions from Childhood to Adulthood. Children's Geographies, 1, 37-52.

\section{Summary}

After the regaining of independence in 1990 Latvia experienced continuous population decline due to negative natural population growth and net migration. Such changes precipitated a decline in accessible services, particularly in rural regions, and related discussions on the accessibility of services and activities in Latvian municipalities.

To investigate the accessibility of services, the travel behavior of young people aged 12 to 20 from home to school and organized out-of-school activities in Jelgava Municipality were analyzed. The data for study were acquired through an online pilot survey $(n=117)$.

Results reveal that the accessibility of school and organized out-of-school activities in Jelgava Municipality is relatively high. More than $65 \%$ of youth can reach their school or organized out-of-school activity location within 15 minutes. The high level of accessibility is a consequence of locating schools in the largest villages of the municipality. The results suggest that if the optimization of the school network will affect the largest villages of Jelgava Municipality, the level of accessibility of schools and organized out-of-school activities will decrease, i.e., the travel time to services will increase. Hence, assessing the socioeconomic context of young people's lives - rather than their travel behavior - is recommended. 